\title{
ОСТАЦИ СРЕДЊОВЕКОВНЕ ЦРКВЕ НА ЛОКАЛИТЕТУ ЦРКВИНА У ЛАЋИСЛЕДУ КОД АЛЕКСАНДРОВЦА ЖУПСКОГ
}

\author{
Дејан С. Радисављевић \\ Филозофски факултет, Универзитет у Београду \\ e-mail: dejanradisavljevicanthro@gmail.com | Оригинални научни рад \\ Примљено: 25. 9. 2020. УДК: 904:726:27-523.2”653”(497.11) \\ Прихваћено: 9. 6.2021. 902.2(497.11)"1972”
}

\begin{abstract}
Апстракт: У раду је посвећена пажна остацима средњовековне триконхалне иркве на локалитету Црквина у селу Лаћислед, у источном делу Жупе александровачке, која је археолошки истражена 1972. године. Резултати ових истражсивања до данас нису публиковани. По облику своје основе ирква у Лаћиследу има великих сличности са истодобном сакралном грађевином на налазишту Црквина у подрудничкој Каменици код Крагујевйа, као и са црквама манастира Горњака и Благовештења у Горьачкој клисури и Св. Стефана у Липовиу код Алексинца. Важно је истаћи да су села Лаћислед, односно средњовековна Врбница, и Каменица током треће деценије 15. столећа улазила у састав баштинских поседа великог челника Радича. Такође, на основу османских дефтера Крушевачког санцака из 16. века дознајемо да се у Лаћиследу налазио манастир посвећен празнику Ваведења Пресвете Богородиие.
\end{abstract}

Кључне речи: Лаћислед, Врбница, Жупа александровачка, велики челник Радич, моравска архитектура, триконхална ирква, османски дефтери, Крушевачки саниак

Село Лаћислед је смештено на источном ободу Жупе александровачке, према Крушевачкој котлини, и налази се поред важне саобраћајнице која спаја град Крушевац са Александровцем. Споменута комуникација, покрај реке Пепељуше, уједно је и најкраћа путна веза између крушевачког дела Западног Поморавља и копаоничког рударског ревира. Овај путни правац је највероватније коришћен још од неолита, кроз касноантички и рановизантијски период, па све до касног средњег века и османских освајања ових простора (Богосављевић-Петровић и Рашковић 2001, 99-122; Рашковић и Берић 2002, 153; Марић 2006, 34; Рашковић et. al 2010, 29-56). ${ }^{1}$

\footnotetext{
${ }^{1}$ Наведену саобраћајницу су током касноантичког и рановизантијског периода штитила утврђења на локалитетима: Градиште (Милошев град) на граници данашњих атара Мрмоша и Лаћиследа, Градиште у Љубинцима код Александровца и Гобеља код Бруса. Случајни археолошки налази са Градишта у Љубинцима указују на живот у утврђењу и током средњег века (Богосављевић-Петровић и Рашковић 2001, 99-122; Рашковић и Берић 2002, 153; Марић 2006, 34; Рашковић, Димовски и Црнобрња 2010, 29-56; Црнобрња-Красић 2020, 195-196, 199).
} 
Средњовековни писани извори не бележе постојање села Лаћислед под овим називом. Прве информације о њему налазимо у османском дефтеру Крушевачког санџака из 1516. године, када је у нахији Крушевац пописано село Врбница, чије је друго име Лаћислед, са 23 дома, четири неожењена и два удовичка домаћинства. Поред села је убележена једна воденица, као и манастир (Лутовац 1980, 18; Зиројевић 1984, 70).

Међутим, у повељи деспота Ђурђа Вуковића издатој великом челнику Радичу를 1430 . године, којом му овај владар потврђује у баштину поседе раније добијене од деспота Стефана Лазаревића (1402-1427), наводе се, поред осталог, и села Врбница (Врьвмица) и Себечевац (Сєвєчєвьц)³ у Крушевачкој власти (Шкриванић 1973, 134; Тошић 1976, 15-16; Pavlikianov 2015, 173-176). ${ }^{4}$ Саопштени податак упућује на закључак да је средњовековна Врбница своје данашње име, Лаћислед, понела у раздобљу између 1429. и 1516. године.

Средњовековно село Врбница је највероватније било смештено на локалитету Селиште, у источном подножју брда Бела Стена (409 м), односно у челенци Селишког потока, леве притоке реке Пепељуше, око 1,5 км западно од средишта данашњег Лаћиследа. ${ }^{5}$ На налазишту се констатују уситњени фрагменати кухињске и трпезне грнчарије, која би се хронолошки могла определити у раздобље од средине 13 . до првих деценија 15. века. $^{6}$

\footnotetext{
2 Челник/велики челник Радич, у доступним средњовековним историјским изворима нигде се не наводи са презименом. Једино се у оснивачкој повељи манастира Враћевшница, исписаној на западној страни југоисточног пиластра у припрати храма, бележи Радичево презиме, од ког је до наших дана сачуван само његов завршни део ,... повикь (вєлики члникь Радичь ... повикь)". Међутим, битно је истаћи да је у Враћевшници данас видљив препис ове повеље у фреско-техници настао у време поновног живописања цркве 1737. године (Тошић 1976, 8).

${ }^{3}$ Данас истоимено село југозападно од Крушевца и североисточно од Александровца (Благојевић 1972, 47; Шкриванић 1973, 134). Средњовековни Себечевац је, судећи према археолошким налазима, био смештен на локалитетима Испод Ђерма и Батал, око 1 км југозападно од садашњег насеља (Рашковић 2011, 160-161). Село Себечевац, у области Крушевца, бележи се и у османском попису из 1444/45. године, у оквиру тимара Јусуфа, гулама Јакуб-беговог, сина Тодора Музака, са четрнаест домова, једним удовичким домаћинством и приходом од 2520 акчи (Зиројевић и Ерен 1968, 392).

${ }^{4}$ Деспот Ђурађ Вуковић је великом челнику Радичу издао две повеље. Првом, из 1429. године, великом челнику се потврђују у баштину поседи раније стечени под деспотом Стефаном Лазаревићем (1402-1427) и они које је добио од угарског краља Жигмунда Луксембуршког (1387-1437). Другом повељом из 1430. године Радичу се потврђују баштински поседи у крушевачком крају, у Жупи и у сливу реке Расине, који су се након 1427/28. године пали у турске руке (Pavlikianov 2015, 157-176).

${ }^{5}$ Поједини аутори средњовековну Врбницу поистовећују са Великом и Малом Врбницом, селима смештеним на левој обали реке Пепељуше, неколико километара низводно од Лаћиследа (Благојевић 1972, 47; Шкриванић 1973, 134; Зиројевић 1984, 70).

${ }^{6}$ Детаљније о убикацији средњовековне Врбнице, потоњег Лаћиследа, видети у: Радисављевић 2020, 73-92. Са непознатог локалитета у атару Лаћиследа потиче и случајни налаз једног комада новца краља Стефана Уроша II Милутина (1282-1321), који је путем откупа доспео у Народни музеј у Крушевцу (Рашковић 2015, 18, 20).
} 
Свакако најзначајнији архитектонски објекат средњовековног наслеђа Лаћиследа представља црква, до наших дана само незнатно очувана. Наиме, око 270 м западно од центра села и регионалног пута КрушевацАлександровац, у равници покрај десне обале Селишког потока, запажају се

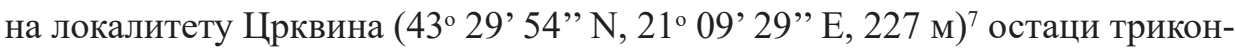
халне цркве моравског стила градње (сл. 1). ${ }^{8}$

Рушевине цркве су откопали мештани Лаћиследа крајем 19. или почетком 20. века, и том приликом је рашчишћен од шута и земље њен унутрашњи простор. ${ }^{9}$ Према забележеном локалном предању саградио ју је легендарни косовски јунак Милош Обилић своме оцу кнезу Јовану Злегињи, сину жупана Злегиње, по ком су имена понела оближња села Горње и Доње Злегиње. ${ }^{10}$

На локалитету Црквина су обављена заштитна археолошка ископавања између 17. и 23. јула 1972. године од стране стручњака Завода за заштиту споменика културе у Краљеву, под руководством Обреније Вукадин. Исте године су изведени и конзерваторски радови на остацима цркве,

\footnotetext{
${ }^{7}$ Битно је нагласити да неки од аутора остатке средњовековне цркве недалеко од центра Лаћиследа погрешно поистовећују са храмом на локалитету Манастирак, на међи са суседним селом Мрмош, иако је реч о двема различитим сакралним грађевинама које су удаљене једна од друге нешто више од 1,4 км (Ристић 1996, 219; Марић 2006, 41). Налазиште Манастирак је смештено у југоисточном подножју брда Обла чука, на чијем се заравњеном врху запажају развалине касноантичког и рановизантијског утврђења Милошев Град (Градиште). На локалитету Манастирак су евидентирани остаци једнобродне сакралне грађевине, зидане употребом ломљеног камена и кречног малтера. Цркву карактерише потковичаста олтарска апсида која је шира од брода. У унутрашњем простору првобитног храма је, пре Другог светског рата, подигнута црква брвнара посвећена Светом Роману. Око цркве, коју је према локалном предању подигао легендарни Милош Обилић над гробом своје мајке Гроздане, простире се некропола, делимично девастирана приликом нивелације терена коју су спровели мештани почетком последње деценије 20. столећа. На основу документације која се чува у Заводу за заштиту споменика културе у Краљеву остаје нејасно да ли су на налазишту претходно спроведена заштитна археолошка ископавања и конзервација преосталих зидова цркве, како се да претпоставити на основу ситуације затечене на терену (Српска православна ирквена оnштина Велика Врбница, Завод за заштиту споменика културе, број: 167, 21. 04. 1992. године, Краљево [Документација Завода за заштиту споменика културе Краљево]; Црнобрња-Красић 2020, 167, 201-202; Теренска истраживања аутора, непубликовано).

${ }^{8}$ Генералитабна карта $1: 75$ 000, секиија Ж. 7. Крушеваи; Topografska karta 1:25 000, Kuršumlija 1-2 (Kupci), broj lista 581-1-2; Topografska karta 1 : 25 000, Kruševac 3-4 (V. Drenova-jug), broj lista 531-3-4.

${ }^{9}$ Према казивању Братислава Карајовића из Лаћиследа за постојање остатака цркве на локалитету Црквина није се знало све до краја 19. или почетка 20. века. Пошто је једна локална врачара указала да се на локалитету налази сакрално здање, прадеда Б. Карајовића је, заједно са другим житељима села, откопао остатке порушених зидова цркве. Казивач Б. Карајовић, октобар 2019. године.

${ }^{10}$ Казивач Б. Карајовић из Лаћиследа, октобар 2019. године: Суседно село Мрмош, према истој легенди, свој назив дугује Мрми, наводном брату Милоша Обилића, који је имао говорну ману, па је само мрмљао.
} 


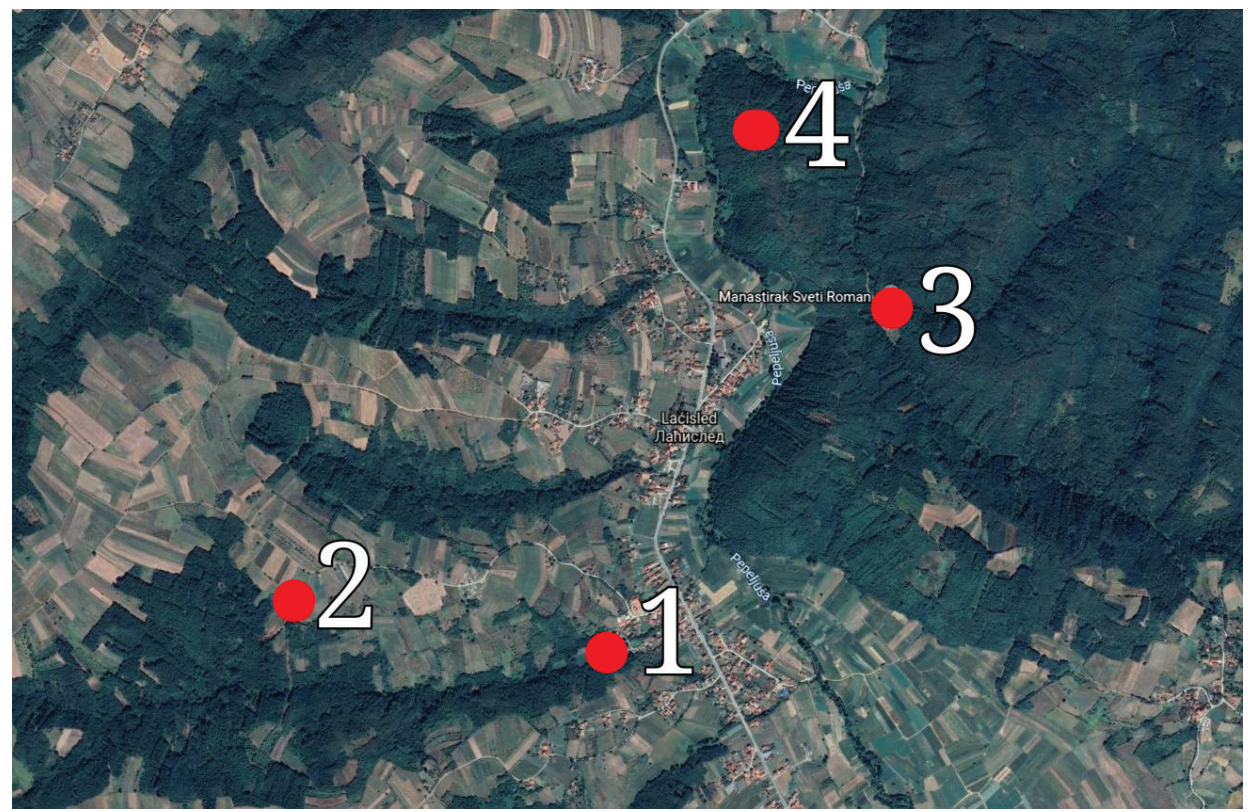

Сл. 1. Локалитет Црквина у Лаћиследу (Жупа александровачка) и друга археолошка налазишта у ближем окружењу: 1. Црквина, 2. Селиште, 3. Манастирак (Црква Светог Романа), 4. Милошев град (Градиште) (Google Earth мапа)

Fig. 1. Site of Crkvina in Laćisled (Župa Aleksandrovačka) and other nearby archaeological sites in the vicinity: 1. Crkvina, 2. Selište, 3. Manastirak (The Church of Saint Roman), 4. Milošev Grad (Gradište) (Google Earth map)

засновани на резултатима претходно спроведених археолошких истраживања, која су укључивала: презиђивање и надзиђивање зидова, дерсовање спољних и унутрашњих зидних површина, нивелацију и презентацију пода и др. Руководилац конзерваторских радова је био арх. Слободан Ђорђевић из Завода за заштиту споменика културе у Краљеву. ${ }^{11}$

У кратком извештају са археолошких ископавања, који је саставила О. Вукадин, наводи се да се у центру Лаћиследа, у дворишту старе школе, налазе остаци цркве тролисне основе, ${ }^{12}$ чији су унутрашњи простор раније откопали мештани села (сл. 2, 3, 4 и 5). Најпре се на локалитету приступило нивелисању повриине унутар остатака храма, као и ослобађању спољашњих лица очуваних зидова од наслага земље. Након припремних радова

\footnotetext{
${ }^{11}$ Извештај Обреније Вукадин: Откопавање Црквине у Лаћиследу у 1972. години (Документација Завода за заштиту споменика културе у Краљеву). Уз краћи прилог саопштен у зборнику „Рашка баштина 1“ Р. Станић даје и цртеж основе цркве (Станић 1975, 312).

${ }^{12}$ Исте податке наводи и М. Лутовац у својој антропогеографској студији Жупе александровачке (Лутовац 1980, 78).
} 


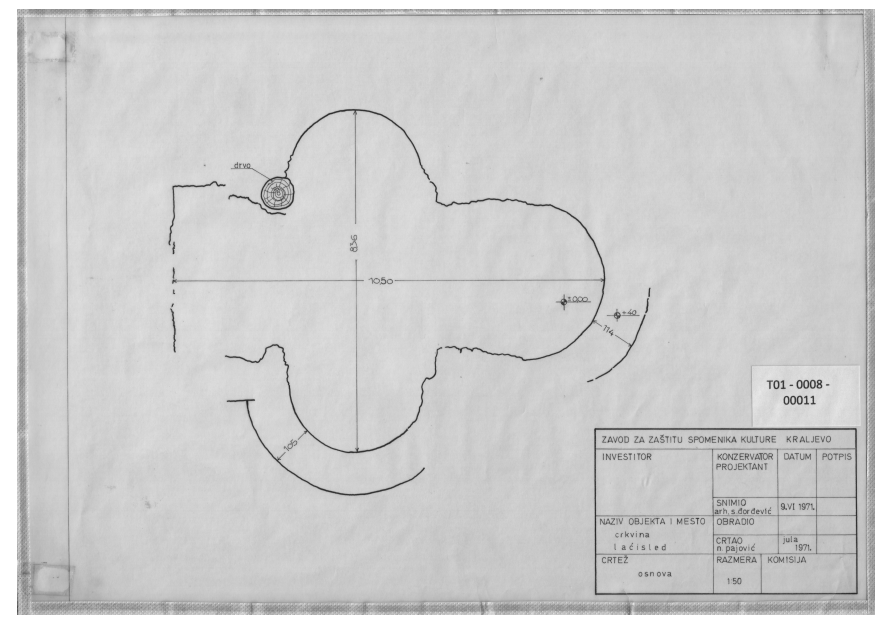

Сл. 2. Локалитет Црквина у Лаћиследу, ситуациони план основе цркве пре почетка археолошких истраживања 1972. године (Документација Завода за заштиту споменика културе Краљево)

Fig. 2. Site of Crkvina in Laćisled, situation plan of the foundations of the church before the beginning of archaeological excavations in 1972

(Documentation of the Cultural Monument Protection Institute in Kraljevo)

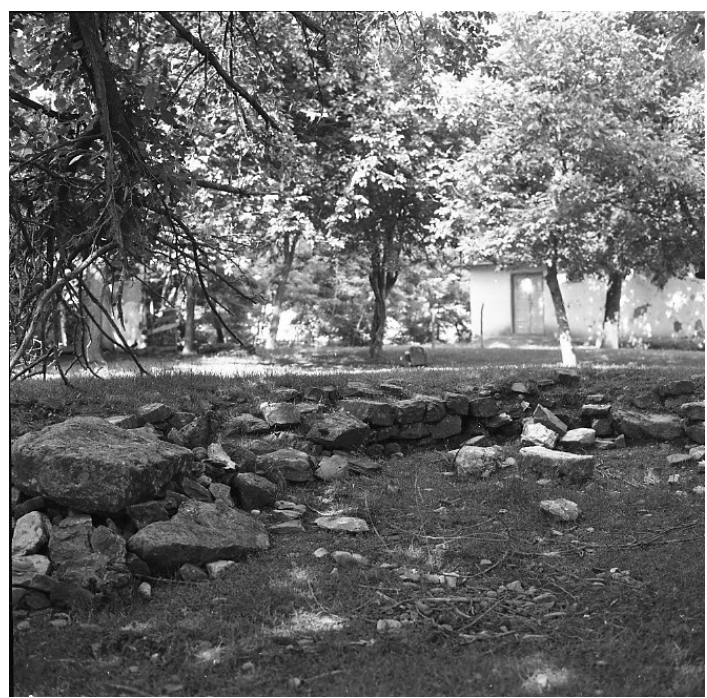

Сл. 3. Локалитет Црквина у Лаћиследу, затечени остаци цркве пре почетка археолошких истраживања 1972. године (Документација Завода за заштиту споменика културе Краљево)

Fig. 3. Site of Crkvina in Laćisled, remains of the church found before the beginning of archaeological excavations in 1972 (Documentation of the Cultural Monument Protection Institute in Kraljevo) 


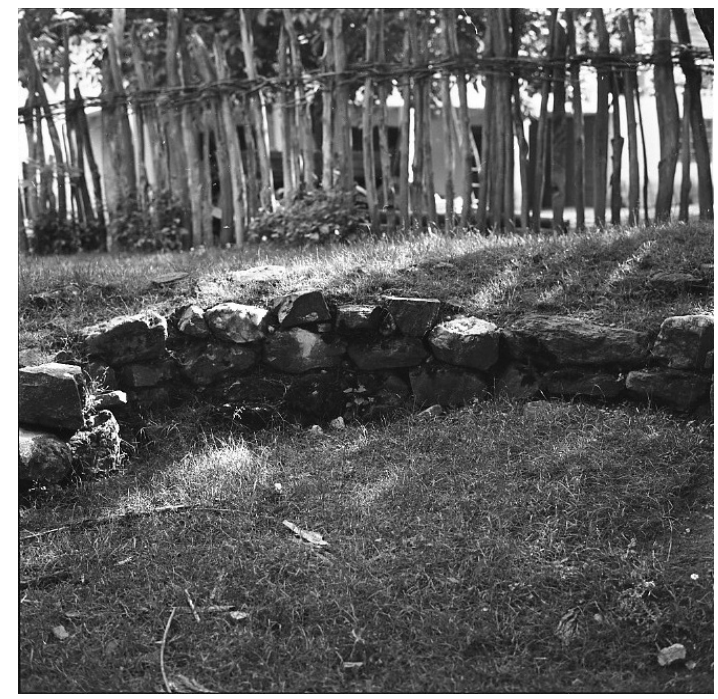

Сл. 4. Локалитет Црквина у Лаћиследу, део очуваног зида цркве пре почетка археолошких истраживања 1972. године

(Документација Завода за заштиту споменика културе Краљево)

Fig. 4. Site of Crkvina in Laćisled, part of a preserved church wall before the beginning of archaeological excavations in 1972

(Documentation of the Cultural Monument Protection Institute in Kraljevo)

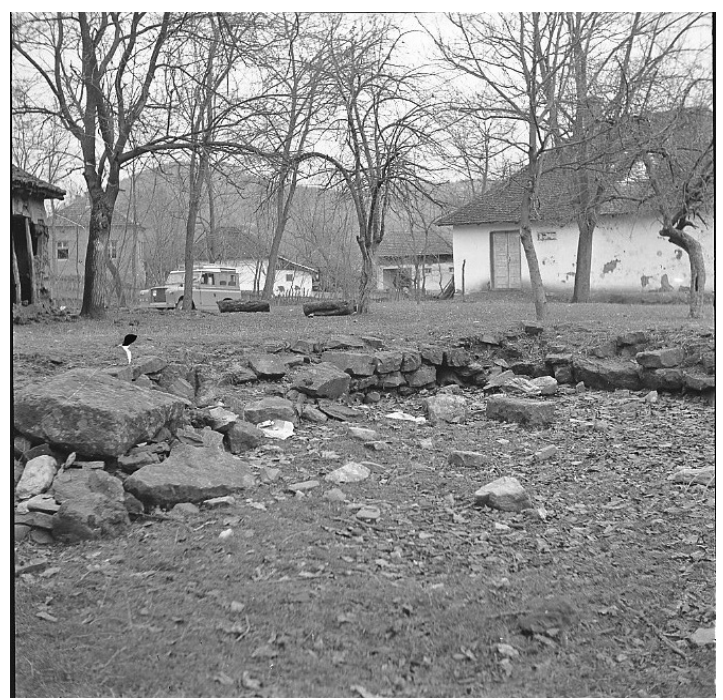

Сл. 5. Локалитет Црквина у Лаћиследу, пре почетка археолошких истраживања 1972. године (Документација Завода за заштиту споменика културе Краљево)

Fig. 5. Site of Crkvina in Laćisled, before the beginning of archaeological excavations in 1972 (Documentation of the Cultural Monument Protection Institute in Kraljevo) 
приступило се сондажном истраживању. ${ }^{13}$ Унутар цркве су постављене две сонде, димензија 2 х 3 м, у којима се ископавало до релативне дубине од 1,60 м. Земља је у њима била жута и потпуно стерилна, те нису констатовани никакви археолошки налази. Евидентирано је да су темељи цркве дубоки око 0,60 м, да су укопани у здравицу (сл. 6 и 7), а да сокл цркве излази за око 0,30 м из равни зида. Са спољашње стране зидова цркве отворене су четири сонде, чије су димензије, такође, 2 х 3 м, док су им дубине ископавања досезале од 1,40 до 1,80 м. Унутар њих су констатована и делимично очишћена четири слободно укопана гроба, правилно оријентисана по оси западисток. ${ }^{14}$ Дубине гробних укопа су биле неједнаке, и кретале су се од 0,95 до 1,28 м. Сви гробови су били без прилога. Судећи према фотографијама насталим током археолошких ископавања, покојници су полагани у опруженом положају са главом ослоњеном на потиљак. У једном случају глава покојника је благо окренута на леву страну и повијена ка грудима. Руке су по правилу савијене у лакту и положене на тело у различитим положајима: лева рука на стомаку, десна на грудима (сл. 8), обе руке оштро савијене у лакту и положене на рамена (сл. 9), и десна рука на карлици, лева на стомаку (сл. 10). ${ }^{15}$ Такође, запажа се да су скелетни остаци покојника били релативно добро очувани. Услед одсуства покретног археолошког материјала црква и некропола нису могле бити ближе хронолошки датоване. ${ }^{16}$ Ипак, на основу тлоцрта, црква би се могла определити у време Моравске Србије, односно у сам крај 14. или прву половину 15 . столећа.

Важно је, на овом месту, истаћи чињеницу да су мештани Лаћиследа приликом рашчишћавања унутрашњег простора цркве крајем 19. или почетком 20. века откопали један слободно укопан гроб у северозападном углу западног травеја наоса, са скелетним остацима покојника и већим бро-

${ }^{13}$ Тачан положај сонди унутар цркве и изван њених зидова није наведен у извештају О. Вукадин. Међутим, на основу фотографија насталих током ископавања на локалитету 1972. године, може се закључити да је једна сонда унутар цркве била постављена уз северни зид олтарске апсиде са проскомидијом, док је друга захватала јужну половину западног травеја наоса.

${ }^{14}$ Тачан положај гробова није могуће прецизније одредити на основу информација саопштених у извештају и доступних фотографија, насталих током археолошких ископавања 1972. године. Скелетни остаци покојника нису померани са својих првобитних положаја и након документовања су поново засути земљом.

15 Фотографија скелетних остатака четвртог покојника се не налази у документацији Завода за заштиту споменика културе у Краљеву.

${ }^{16}$ Извештај Обреније Вукадин: Откопавање Црквине у Лаћиследу у 1972. години (Документација Завода за заштиту споменика културе у Краљеву). Веома је индикативно да у шуту и на преосталим зидовима нису пронађени фрагменти фресака, што највероватније указује да црква, као и храм оближњег манастира Дренче (1382), никада није била живописана (Гаврић и Ковачевић 2015, 34). 


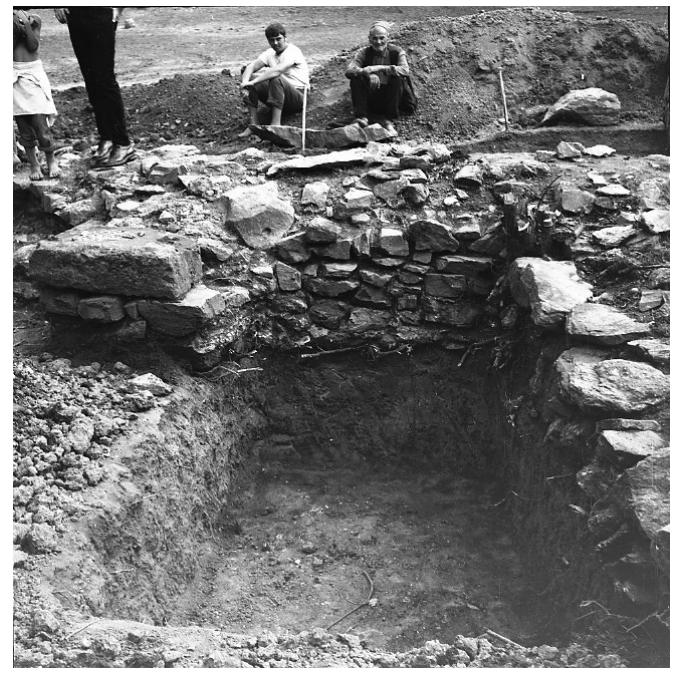

Сл. 6. Локалитет Црквина у Лаћиследу, археолошка сонда у јужној половини западног травеја наоса (фотографија из 1972, Документација Завода за заштиту споменика културе Краљево)

Fig. 6. Site of Crkvina in Laćisled, the archaeological trench in the southern half of the western part of the church nave (photo from 1972,

Documentation of the Cultural Monument Protection Institute in Kraljevo)

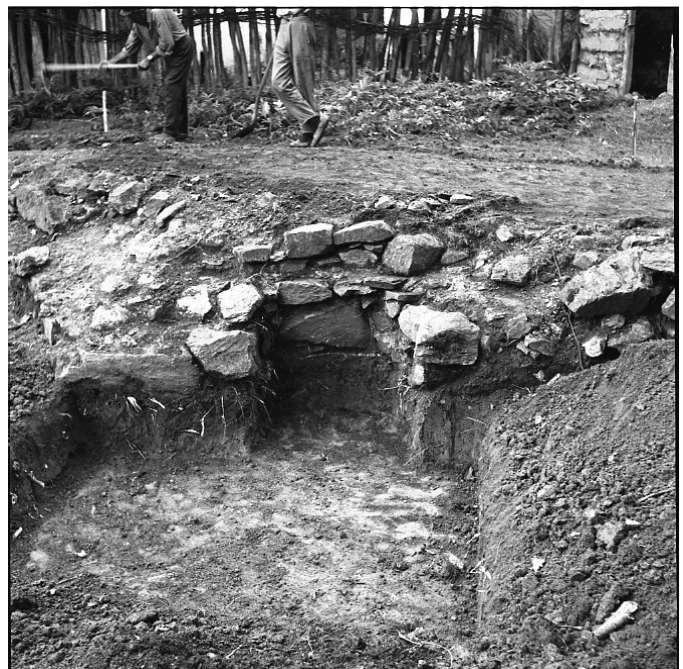

Сл. 7. Локалитет Црквина у Лаћиследу, археолошка сонда уз северни зид олтарске апсиде са нишом проскомидије (фотографија из 1972, Документација Завода за заштиту споменика културе Краљево)

Fig. 7. Site of Crkvina in Laćisled, the archaeological trench next to the northern wall of the altar apse and the niche for proscomedia (photo from 1972, Documentation of the Cultural Monument Protection Institute in Kraljevo) 


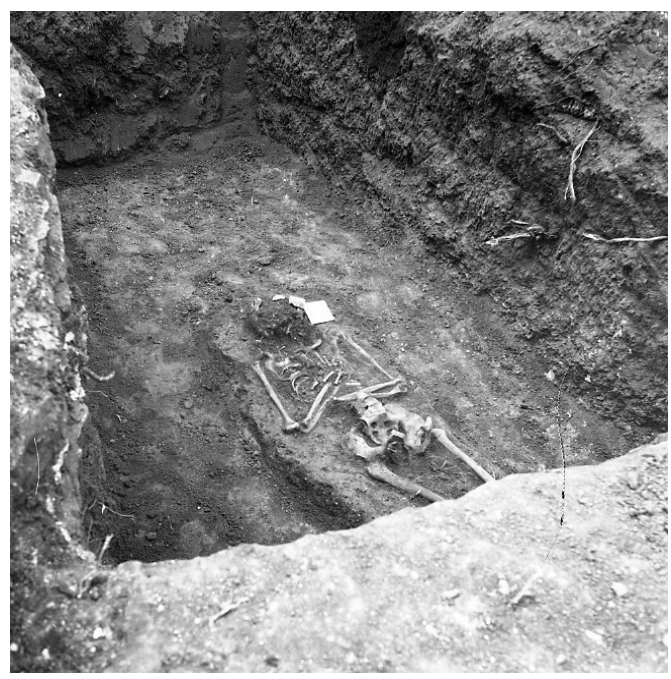

Сл. 8. Локалитет Црквина у Лаћиследу, делимично откопан гроб (фотографија из 1972, Документација Завода за заштиту споменика културе Краљево)

Fig. 8. Site of Crkvina in Laćisled, a partially excavated grave (photo from 1972, Documentation of the Cultural Monument Protection Institute in Kraljevo)

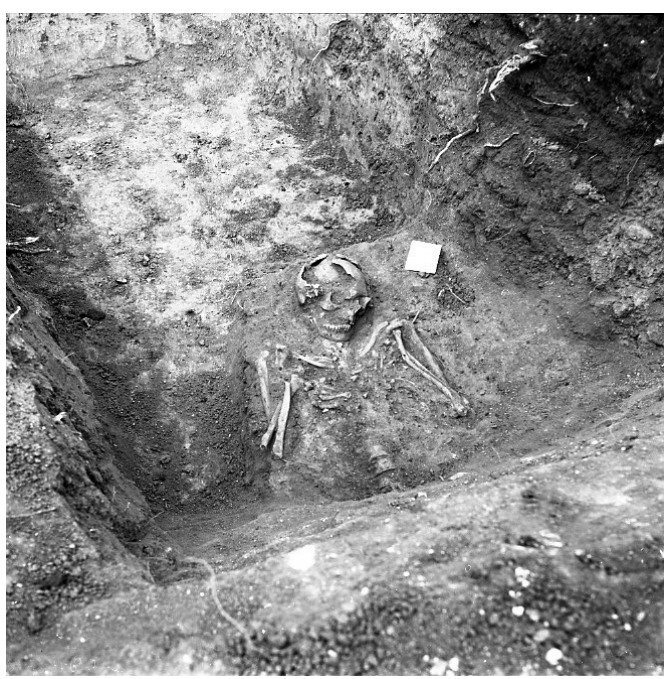

Сл. 9. Локалитет Црквина у Лаћиследу, један од делимично откопаних гробова (фотографија из 1972, Документација Завода за заштиту споменика културе Краљево)

Fig. 9. Site of Crkvina in Laćisled, one of the partially excavated graves (photo from 1972, Documentation of the Cultural Monument Protection Institute in Kraljevo) 


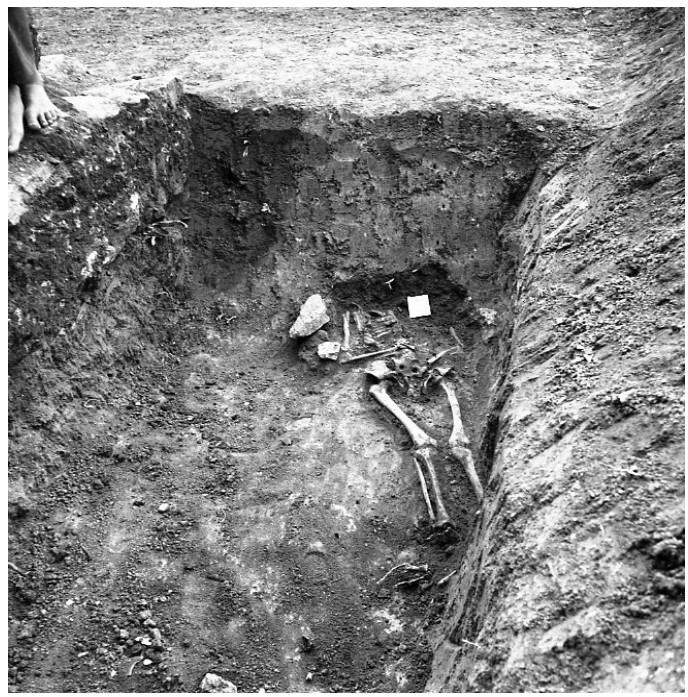

Сл. 10. Локалитет Црквина у Лаћиследу, делимично откопан гроб (фотографија из 1972, Документација Завода за заштиту споменика културе Краљево)

Fig. 10. Site of Crkvina in Laćisled, a partially excavated grave (photo from 1972,

Documentation of the Cultural Monument Protection Institute in Kraljevo)

јем сребрне лоптасте дугмади (пуц̧ета), која нису сачувана. ${ }^{17}$ Могло би се претпоставити, судећи према положају гробног укопа, да је на том месту сахрањена особа вишег друштвеног сталежа, највероватније неки локални властелин, сам ктитор или члан његове породице.

Гробови ктитора у северозападном углу наоса су посведочени, нпр. у цркви у Радошићу код Рашке (14. век), у Новој Павлици код Брвеника ${ }^{18}$ и у Богородици Пречистој у Горњачкој клисури, подно тврђаве Ждрело ${ }^{19}$ (Мадас и Гајић 1983, 228-231; Радичевић и Булић 2014, 123-125, 128-129).

Такође, требало би напоменути да су мештани приликом копања темеља за нову звонару и парохијски дом девастирали неколико гробова, око 10 м источно од остатака средњовековног храма. ${ }^{20}$ Током изградње нове

\footnotetext{
${ }^{17}$ Казивач Б. Карајовић, октобар 2019. године.

${ }^{18}$ Нова Павлица је саграђена изеђу 1381. и 1386, а живописана 1387. године. У северозападном углу наоса су сахрањена браћа и ктитори, Стефан и Лазар Мусић (Радичевић и Булић 2014, 123).

19 У северозападном углу наоса ове цркве су око средине 14. века сахрањене су две особе властеоског рода, које су након монашења понеле име Илија и Теодора, као и њихово двоје деце (Мадас и Гајић 1983, 228-231; Радичевић и Булић 2014, 128).

${ }^{20}$ Наведене податке су нам саопштили казивачи Братислав Карајовић и Љуба Новаковић из Лаћиследа, који су били и учесници ископавања 1972. године, и у чијем је власништву раније био простор локалитета.
} 


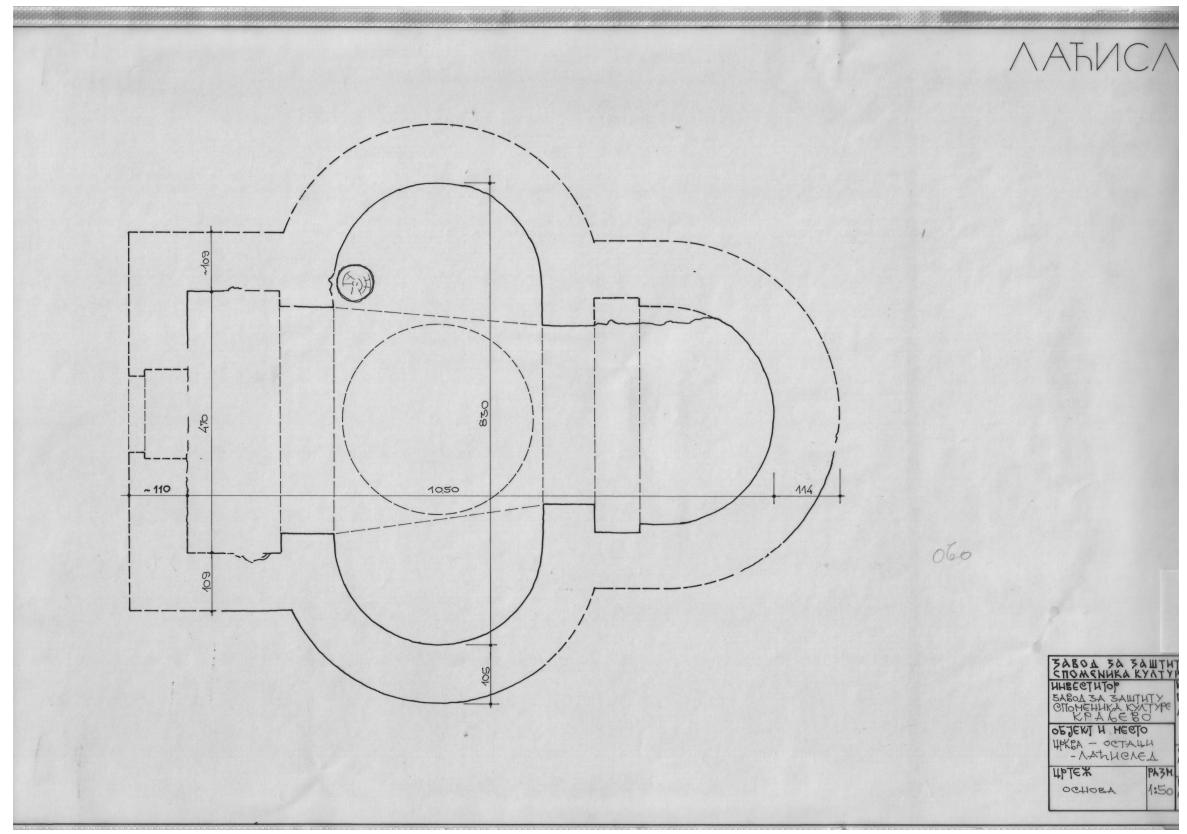

Сл. 11. Локалитет Црквина у Лаћиследу, основа цркве

(Документација Завода за заштиту споменика културе Краљево)

Fig. 11. Site of Crkvina in Laćisled, church plan

(Documentation of the Cultural Monument Protection Institute in Kraljevo)

цркве посвећене празнику Вазнесења Господњег, ${ }^{21}$ на терену југоисточно од првобитне сакралне грађевине, гробови нису констатовани. На основу изнетих запажања може се претпоставити да је некропола захватала простор непосредно уза зидове цркве, као и да се протезала даље ка истоку.

Црква је у основи триконхос сажете варијанте уписаног крста, без припрате, унутрашњих димензија 10,50 х 8,30 м (сл. 11, 12, 13). Њени зидови су грађени притесаним каменом (шкриљац, пешчар, кварцит) и речним облуцима, везаним беличастим кречним малтером, у релативно правилном слогу. ${ }^{22}$ Висина зидова након конзервације са унутрашње стране варира од 1,05 м у североисточном делу зида олтарске апсиде, до 1,20 м у западном

\footnotetext{
${ }^{21}$ Градња нове цркве Вазнесења Господњег у Лаћиследу отпочела је 2000. године по пројекту арх. Живка Миленковића. Освештао ју је епископ крушевачки Давид 1. септембра 2019. године. Лаћислед данас припада парохији Првој великоврбничкој, односно Архијерејском намесништву александровачко-бруском Крушевачке епископије. Званични сајт Крушевачке епархије, http://www.eparhijakrusevacka.com.

${ }^{22}$ Опис архитектуре цркве проистекао је из ауторових обилазака локалитета у више наврата од 2018. до 2020. године. Веома сажет опис остатака лаћиследске цркве и њене архитектуре дају В. Ристић и С. Црнобрња-Красић (Ристић 1996, 219; Црнобрња-Красић 2020, 200).
} 


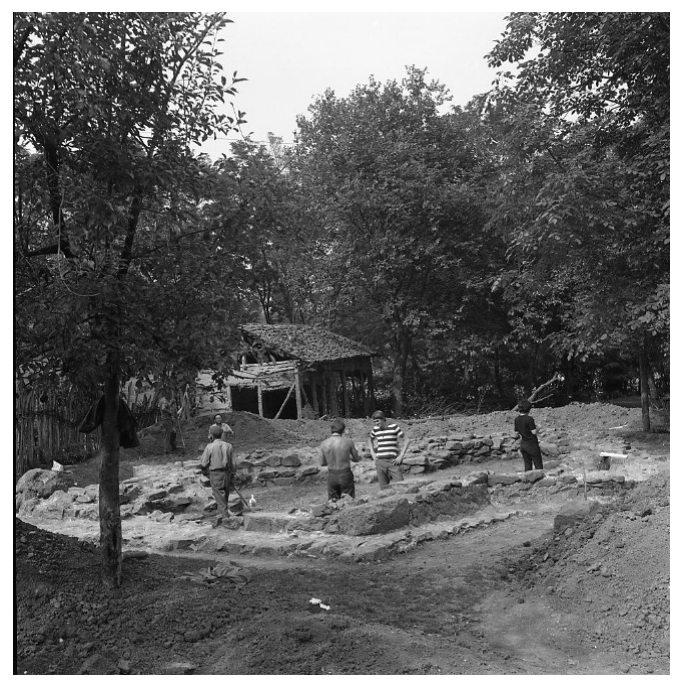

Сл. 12. Локалитет Црквина у Лаћиследу, остаци зидова цркве након археолошких истраживања (фотографија из 1972, Документација Завода за заштиту споменика културе Краљево)

Fig. 12. Site of Crkvina in Laćisled, preserved church walls after archaeological excavations (photo from 1972, Documentation of the Cultural Monument Protection Institute in Kraljevo)

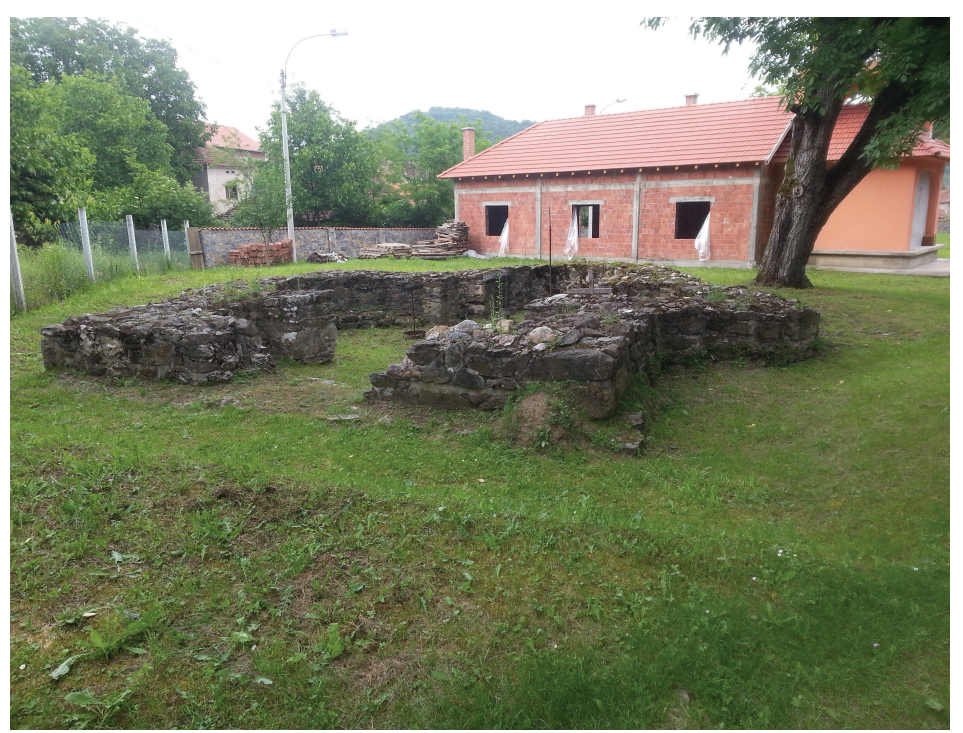

Сл. 13. Локалитет Црквина у Лаћиследу, остаци триконхалне цркве, поглед са југозапада - данашње стање (фотографија Д. Радисављевић)

Fig. 13. Site of Crkvina in Laćisled, remains of the triconch church, exterior view from the south-west - present condition (photo D. Radisavljević) 
делу зида северне певнице. Са спољашње стране зидови цркве не прелазе висину од 0,90 м (југозападни угао западног травеја), док им је дебљина углавном уједначена и креће се у распону од 1,05 до 1,14 м.

Унутрашњи простор цркве, који се сужава од запада ка истоку, паровима пиластара неједнаких димензија (СИ - 0,92 х 0,60 м, ЈИ - 0,92 х 0,97 м, C3 - 0,93 х 0,73м и J3 - 0,92 х 0,74 м) издељен је на три неједнака травеја. Олтарска апсида, која заузима читаву ширину брода, полукружна је са унутрашње и спољашње стране (сл. 14, 15). Дубина олтарског простора износи 2,40 м. У северном и јужном зиду источног травеја обликована је по једна ниша. Јужна је правоугаоног облика, и имала је улогу ђаконикона $(0,97$ x 0,77 x 0,63 м), док је северна издуженог полукружног пресека и била је у функцији проскомидије $(0,82$ × 0,60 х 0,76 m).

Северна и јужна апсида, полукружних зидова са унутрашње и спољашње стране, заједно са поткуполним простором чине централни травеј наоса, који је паром пиластара одвојен од мањег западног травеја (сл. 16, 17). Изнад наоса се највероватније издизала купола, која је почивала на луковима ослоњеним на пиластре.

Црква је имала један централно позициониран улаз на западној страни, ширине око 1,80 м, али се његов првобитни изглед, услед девастације, не може у потпуности сагледати.

Запажа се да је садашњи импровизовани стуб часне трпезе начињен од фрагмената средњовековних надгробних плоча. Поједини дислоцирани и поломљени примерци се уочавају северно и јужно од зидова цркве. Можда би се могло претпоставити да су се ови надгробници првобитно налазили над гробовима у непосредном окружењу цркве, па накнадно постали део часне трпезе.

У доступним средњовековним писаним изворима не бележи се постојање цркве у Лаћиследу (Врбници). У већ споменутој повељи деспота Ђурђа из 1430. године наводи се само Радичева ктиторија на реци Грабовничици, недалеко од Бруса, посвећена празнику Благовести (,црькөвь

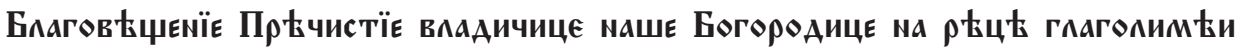
Гравовничица, щө си к сьзидаль своимь троуашмь”). (Стојановић 1890, 4; Pavlikianov 2015: 174-175). ${ }^{23}$

Средњовековна лаћиследска црква, према начину градње и просторној артикулацији, има најближе аналогије са недавно откривеном сакралном грађевином у подрудничкој Каменици, западно од Крагујевца. Каменица је, у

\footnotetext{
${ }^{23}$ Радичева црква посвећена Благовестима највероватније се налазила у данашњем селу Велика Грабовница, на левој обали Грабовничке реке, десне притоке Расине, око 6 км западно од Бруса (Благојевић 1972, 46; Шкриванић 1973, 134; Ристић 1996, 214).
} 


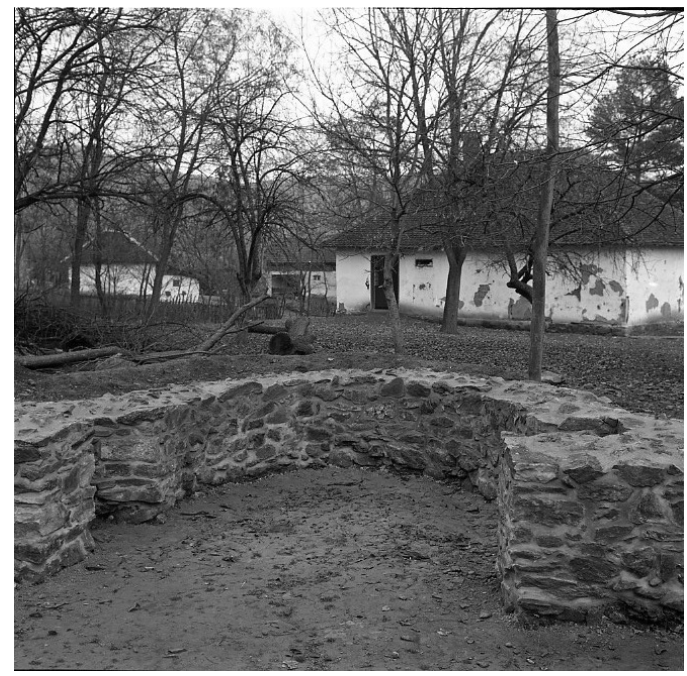

Сл. 14. Локалитет Црквина у Лаћиследу, олтарски простор цркве након конзервације зидова 1972. године (Документација Завода за заштиту споменика културе Краљево)

Fig. 14. Site of Crkvina in Laćisled, interior altar space after conservation of the church walls in 1972 (Documentation of the Cultural Monument Protection Institute in Kraljevo)

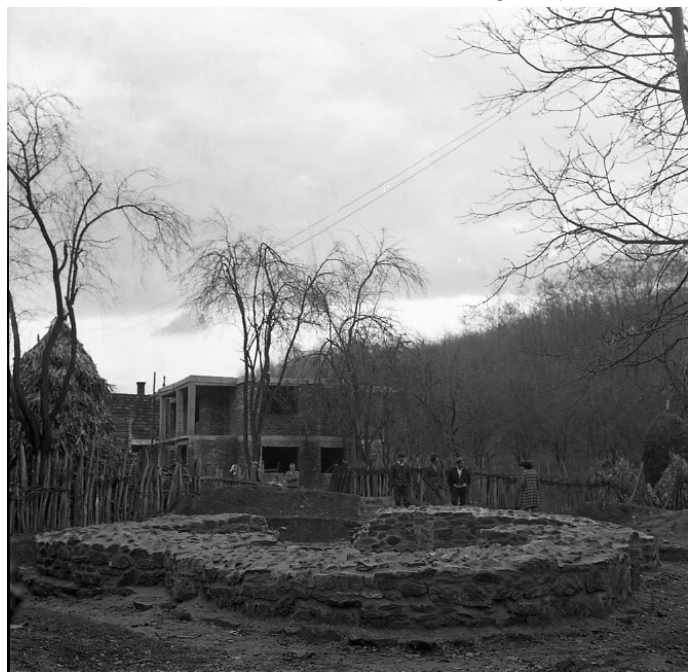

Сл. 15. Локалитет Црквина у Лаћиследу, остаци цркве након конзервације, поглед са истока (фотографија из 1972, Документација Завода за заштиту споменика културе Краљево)

Fig. 15. Site of Crkvina in Laćisled, remains of the church after conservation, exterior view from the east (photo from 1972, Documentation of the Cultural Monument Protection Institute in Kraljevo) 


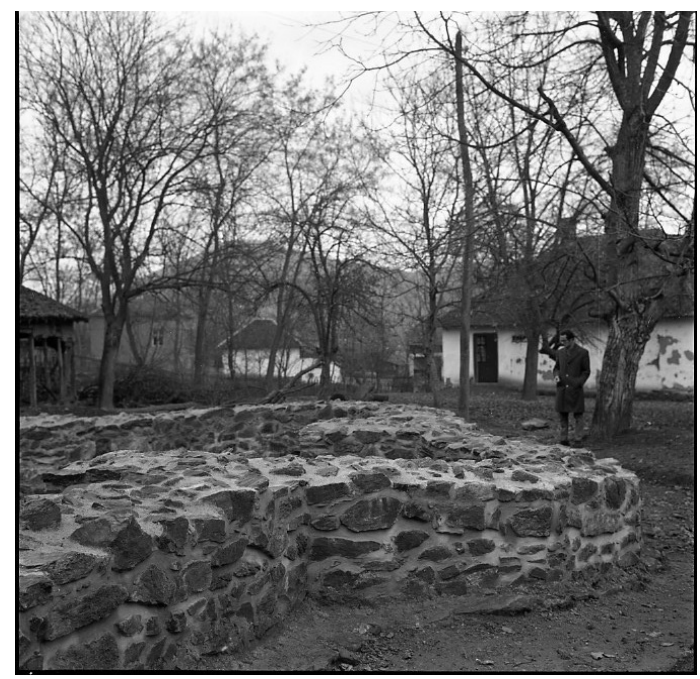

Сл. 16. Локалитет Црквина у Лаћиследу, спољашње лице зида јужне апсиде, након конзервације (фотографија из 1972, Документација Завода за заштиту споменика културе Краљево)

Fig. 16. Site of Crkvina in Laćisled, exterior wall of the southern church apse, after conservation (photo from 1972, Documentation of the Cultural Monument Protection Institute in Kraljevo)

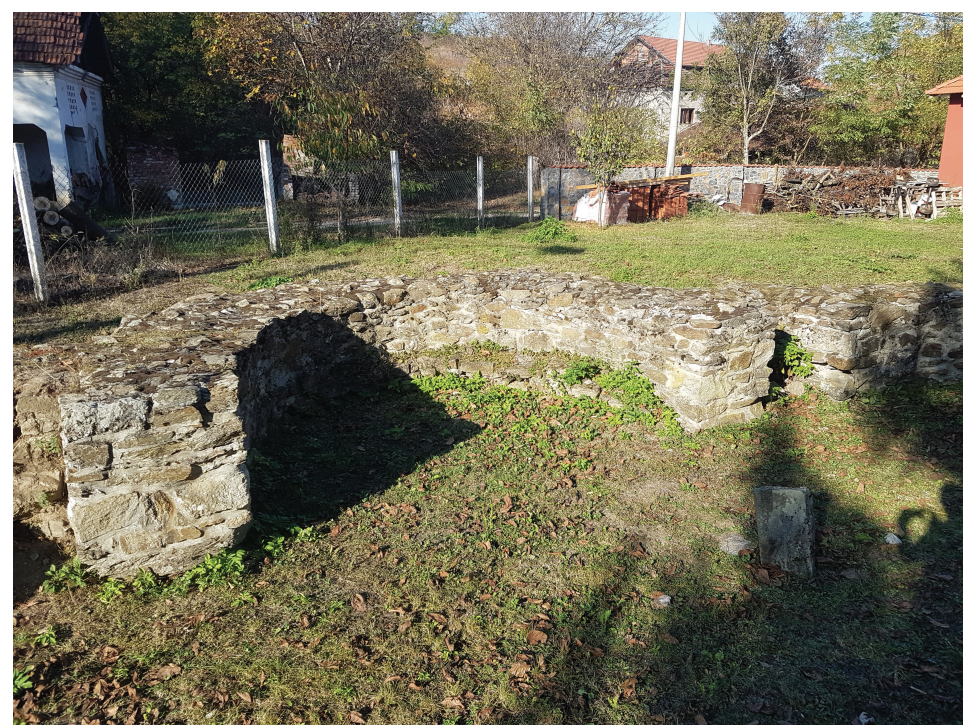

Сл. 17. Локалитет Црквина у Лаћиследу, унутрашње лице зида северне апсиде - данашње стање (фотографија Д. Радисављевић)

Fig. 17. Site of Crkvina in Laćisled, interior view of the northern church apse wall - present condition (photo D. Radisavljević) 
оквиру рудничког метоха, ${ }^{24}$ улазила у састав Радичевих баштинских поседа, како је забележено у повељи деспота Ђурђа овом властелину из 1429. године

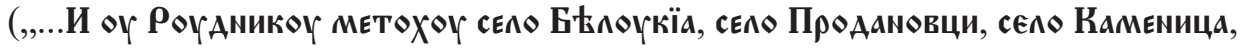

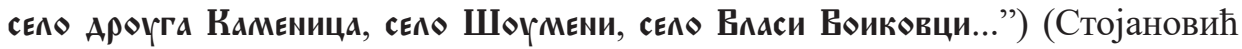
1890, 3; Шкриванић 1973, 131; Pavlikianov 2015, 168, 172). Исто село се наводи и у Радичевој повељи из 1430/31. године, којом је светогорском манастиру Кастамонит, чији је он био нови ктитор, даривао двадесет литара сребра годишње. Овој светогорској обитељи је након његове смрти требало да припадне, поред прихода од седам села и половине од делова у Руднику, и половина кола, односно топионице, у Каменици, док је друга половина припадала Манастиру Св. Ђорђа у Враћевшници. („И А Тлове што имамь оү Роүаникоү,

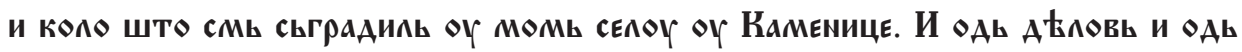

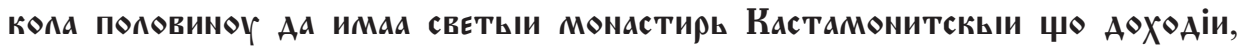

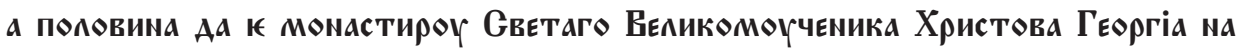
Вракєєвчици.”) 25 (Стојановић 1890, 34; Новаковић 1912, 549; Шкриванић 1973, 135-136; Pavlikianov 2015, 176-177; Ивановић 2018, 70).

Археолошки истражена триконхална сакрална грађевина без припрате, у Каменици на локалитету Црквина, око 3 км северозападно од центра села и изнад леве обале Каменичке реке, има готово идентичну основу као црква у Лаћиследу и сличне димензије (спољашње димензије: Каменица - 10,60 х 10,60 м, Лаћислед - 12,75 х 10,45 м). Разлика у односу на лаћиследски храм огледа се у присуству седам имитација лезена на зиду олтарске апсиде, као и у чињеници да је олтарски простор каменичке сакралне грађевине нешто шири и плићи. На основу „начина градње, облика основе, истражених гробова и покретног археолошког материјала откривеног у цркви и око ње" црква у Каменици је датована у 15. век, односно у његову прву половину (Каличанин-Крстић и Шаренац 2018, 228-236). ${ }^{26}$

Обликом своје основе, начином градње и унутрашњом организацијом простора, црква у Лаћиследу, уз нека разлике, има великих подударности

\footnotetext{
${ }^{24}$ О убикацији средњовековног Рудника и границама његовог градског метоха, видети у: Петровић и Булић 2009, 43-61; Мишић 2018, 9-11. О градском метоху на простору српских земаља током средњег века, видети: Петровић 2015, 139-150.

${ }^{25}$ Исти податак о половини кола у Каменици проналазимо и у ктиторском фреско-натпису у припрати цркве манастира Враћевшнице, насталом приликом поновног фрескописања храма 1737. године. Претпоставља се да његов текст верно понавља садржај првобитног ктиторског натписа из 1430/31. године (Стародубцев 2014, 117-118; Pavlikianov 2015, 187-190).

${ }^{26}$ Црква у Каменици је подигнута на старијој некрополи, која се на основу налаза једног надгробног белега са уклесаним натписом (око 1370. године), секундарно употребљеног као надвратник западног портала, може хронолошки определити у 14. век (Каличанин-Крстић и Шаренац 2018, 228-236).
} 
и са храмовима манастира Горњака (Ждрела) (1376/77-1380) и Благовештења (последња четвртина 14 - почетак 15. века) у Горњачкој клисури, као и са првобитном Црквом Св. Стефана (у средњем веку Преображење Христово) у Липовцу код Алексинца (девета деценија 14. столећа) ${ }^{27}$ (Бошковић 1950, 188-194; Бошковић 1951, 243-244; Мадас и Гајић 1983, 223-224; Ристић 1996, 210, 214-215, 220, 222; Цветковић 1999, 79-81; Поповић 2002, 161162, 165-176; Мишић 2010, 121-128; Радичевић и Булић 2014, 119-120).

Једноставни облик триконхоса, масивни зидови и одсуство декоративне камене пластике, сврставају лаћиследску цркву у круг скромнијих моравских сакралних здања, а истовремено указују и на ктитора слабијих материјалних могућности и „скученог поимања ове (моравске) уметности” (Бабић 1972, 145; Ђурић 1990, 23).

На основу изнетих запажања, може се претпоставити да средњовековни лаћиследски храм највероватније представља задужбину неког непознатог локалног властелина и његову гробну цркву, која је убрзо након изградње преузела улогу парохијског храма, те се из тог разлога, попут цркве у Каменици (1429), не бележи у повељи деспота Ђурђа великом челнику Радичу из 1430. године. Примамљивом се чини претпоставка да би овај угледни и моћни властелин могао бити градитељ цркава у Лаћиследу (Врбници) и Каменици, ${ }^{28}$ с обзиром на то да су оба села током треће деценије 15. столећа, а можда и нешто раније, улазила у састав његових баштинских поседа. C друге пак стране, не сме се одбацити ни могућност да је црква у Лаћиследу (Врбници) подигнута и пре него што је, у доба деспота Стефана Лазаревића, ово село дато у баштину великом челнику Радичу.

Тачно време зидања лаћиследске цркве, без додатних систематских археолошких истраживања, остаје за сада упитно. У сваком случају, до њене изградње је свакако дошло пре 1427/28, ${ }^{29}$ када град Крушевац са ближом околином, са изузетком краћег раздобља између 1451. и 1453. године, трајно улази у састав Османског царства (Зиројевић и Ерен 1968, 377-416; Мишић 2011, 65-66).

\footnotetext{
${ }^{27}$ Цркву Ваведења манастира Горњака (Ждрела) изградио је кнез Лазар за монаха и испосника Григорија Горњачког и његову братију, док ктитор храма манастира Благовештења није познат. Благовештење је свакако подигнуто пре 1429. године, када га у једном запису спомиње јеромонах Теодор, познатији као Инок из Далше (Дајше). Првобитну придворну цркву у Липовцу је саградила непозната властеоска породица. Цркву посвећену празнику Преображења обновио је инок Герман 1398/99. године, када јој је призидана припрата и успостављено општежиће (Стародубцев 2016, 72, 74, 90, са старијом литературом).

${ }^{28}$ У прилог овој претпоставци иде и забележено локално предање да је цркву на локалитету Црквина или Кастун у Каменици саградио велики челник Радич Поступовић (Драгић 1921, 272).

29 В. Ристић је цркву, коју сматра придворицом, датовао, према нашем мишљењу сувише рано, у шесту или седму деценију 14. века (Ристић 1996, 219).
} 
Доцније, у османском дефтеру Крушевачког санџака из 1516. године, како смо већ саопштили, поред села Врбнице, чије је друго име Лаћислед, у Крушевачкој нахији, уписан је и један манастир (Лутовац 1980, 18).

Манастир Пречистог Ваведења ${ }^{30}$ је поред истог села пописан и у дефтеру Крушевачког санџака из 1530. године, са приходом од 415 акчи. Године 1536. у манастиру су живела два калуђера и плаћала годишњи порез од 254 акчи. Неколико деценија касније (око 1570) забележен је само један монах, и исти износ дажбина. Последњи пут се Пречисто Ваведење спомиње у османском дефтеру из 1584. године, са умањеним приходом од 250 акчи (Зиројевић 1984, 70).

На овом степену истражености развалине цркве недалеко од центра Лаћиследа не могу се поуздано поистоветити са манастиром Пречисто Ваведење из османских извора, с обзиром на то да се на међи атара овог села са суседним Мрмошем налазе остаци једнобродне сакралне грађевине на локалитету Манастирак. ${ }^{31}$

Сумирајући изнете чињенице долазимо до закључка да триконхална црква у Лаћиследу, односно средњовековној Врбници, највероватније представља задужбину и гробну цркву неког непознатог локалног властелина. Начин градње и одсуство декоративне камене пластике сврставају овај храм у групу скромнијих моравских сакралних здања, и одају ктитора слабијих материјалних могућности. Остаје за сада отворено питање о тачном времену његове изградње. Међутим, на основу расположивих историјских података може се поуздано претпоставити да је лаћиследска црква подигнута пре 1427/28. године, односно у раздобљу које је претходило османском освајању Крушевца и његове ближе околине. Током 16. века турски пописивачи бележе поред Лаћиследа (Врбнице) манастир посвећен празнику Ваведења Пресвете Богородице, који се за сада, без додатних истраживања, не може поуздано идентификовати са остацима цркве на локалитету Црквина. С обзиром на то

\footnotetext{
${ }^{30}$ О. Зиројевић је манастир Пречисто Ваведење погрешно поистоветила са Црквом Св. Николе у Великој Врбници, која је саграђена током владавине кнеза Милоша (прва половина 19. века) (Зиројевић 1984, 70), превиђајући чињеницу да се у османским дефтерима из 16. века манастир јасно наводи поред села Врбнице, чије је друго име Лаћислед. У истим дефтерима су пописана и села Горња, Средња и Доња Врбница (Лутовац 1980, 18; Радисављевић 2020, 73-92).

31 У будућности би на локалитетима Црквина и Манастирак требало спровести систематска археолошка истраживањима, или пак геомагнетна снимања, која би помогла да се коначно разреши дилема око убикације манастира Пречисто Ваведење, забележеног у османским дефтерима из 16. века.
} 
да мештани не познају првобитну посвету храма, ${ }^{32}$ до његовог напуштања и рушења је морало доћи прилично рано, можда баш у немирним временима самог краја 16. века или током хабзбуршко-турских сукоба крајем 17. столећа.

Захвалница: Срдачно овом приликом захваљујемо Заводу за заштиту споменика културе у Краљеву и колеги Војкану Милутиновићу, на уступљеној документацији насталој током и након археолошких истраживања и конзервације остатака цркве на локалитету Црквина у Лаћиследу 1972. године. Такође, велику захвалност на пруженим информацијама дугујемо и житељима Лаћиследа, Братиславу Карајовићу и Љуби Новаковићу.

\section{БИБЛИОГРАФИЈА}

Бабић, Г. 1972. Друштвени положај ктитора у Деспотовини, у: Моравска школа и њено доба. Научни скуп у Ресави 1968, ур. В. Ђурић, Београд: Филозофски факултет, Одељење за историју уметности, 143-155.

Благојевић, М. 1972. Манастирски поседи крушевачког краја. Крушеваи кроз векове, Зборник реферата са симпозијума одржаног од 4. до 9. октобра 1971. у Крушевuy, ур. Адам Стошић и др., Крушевац: Народни музеј Крушевац, 25-48.

Богосављевић-Петровић, В. и Рашковић, Д. 2001. Рановизантијско утврђење на брду Гобеља код Бруса. Саопитења XXXII-XXXIII (2000-2001): 99-122.

Бошковић, Ђ. 1950. Средњовековни споменици североисточне Србије. Старинар (H. c.) I: $185-218$.

Бошковић, Ђ. 1951. Средњовековни споменици Источне Србије II. Старинар (н. с.) II: $221-244$.

Вукадин, О. 1972. Откопавање Црквине у Лаћиследу у 1972. години (Документација Завода за заштиту споменика културе у Краљеву).

Гаврић, Г. и Ковачевић, М. 2015. Манастир Дренча, од рушевине до храма. Краљево: Завод за заштиту споменика културе.

Драгић, М. 1921. Гружа. Антропогеографска испитивања, Насеља српских земаља: расправа и грађа X, Српски етнографски зборник XXI, Београд: Српска краљевска академија, 151-382.

Ђурић, В. 1990. Друштво, држава и владар у уметности у доба династије Лазаревић-Бранковић, Зборник Матице српске за ликовне уметности 26: 13-46.

Зиројевић, О. 1984. Цркве и манастири на подручју Пећке патријаршије до 1683. године. Београд: Историјски институт у Београду, Народна књига.

\footnotetext{
32 Родоначелници данашњих фамилија, пореклом из Црне Горе (Морача, околина Колашина, Пипери, Бјелопавлићи, Горње Полимље), са Пештера и из копаоничког подгорја (села Блажево, Осредци и Град), доселили су се Лаћислед почев од средине 18. века (Лутовац 1980, 78-79).
} 
Зиројевић, О. и Ерен, И. 1968. Попис области Крушевца, Топлице и Дубочице у време прве владавине Мехмеда II (1444-1446), Врағски гласник IV: 377-416.

Ивановић, М. 2018. „Заборављени” ктитори у средњовековној Србији. Иницијал, Часопис за средюовековне студије 6: 47-72.

Каличанин-Крстић, М. и Шаренац, Б. 2018. Археолошка истраживања у Каменици од 2012. до 2015. године. У: Рудник и Венчаи са околином у средњем веку и раној модерни, Тематски зборник радова са научног скупа одржаног 21. октобра 2017. године у Народном музеју у Аранђеловиу, ур. С. Мишић и др., Аранђеловац, 227-246.

Лутовац, М. 1980. Жупа александровачка - антропогеографска испитивања. Cpnски етнографски зборник XСIII, Насеља и порекло становништва 43, Београд.

Мадас, Д. и Гајић, А. 1983. Надгробне плоче и гробови ктитора цркве Богородице Пречисте у комплексу Ждрела у Горњачкој клисури. Саопштењ $\mathrm{XV}$ : 221-242.

Марић, М. 2006. Археолошки локалитети на територији Жупе александровачке, Жупски зборник 1: 28-44.

Мишић, С. 2010. Петрушко и Липовачко крајиште од половине XIV века до 1459. године, у: Историја Поморавља и два века од Варваринске битке, ур. Д. Милошевић, Крушевац: Историјски архив Крушевац, 121-128.

Мишић, С. 2011. Обнова Деспотовине и њене границе (1444-1459), у Пад српске деспотовине 1459. године, Зборник радова са научног скупа одржаног 12-14. новембра 2009. године, ур. М. Спремић, Српска академија наука и уметности, Научни скупови књига CXXXIV, Одељење историјских наука књига 32, Београд, 63-73.

Мишић, С. 2018. Територијално-управна организација Рудника и околине (12-15. век), у: Рудник и Венчаи са околином у средњем веку и раној модерни, Тематски зборник радова са научног скупа одржаног 21. октобра 2017. године у Народном музеју у Аранђеловиу, ур. С. Мишић и др., Аранђеловац, 7-14.

Новаковић, С. 1912. Законски споменици српских држава средњег века, прикупио и уредио Стојан Новаковић, Посебна издања Српска краљевска академија 37, Философски и филолошки списи књига 10, Београд: Српска краљевска академија.

Pavlikianov, C. 2015. The Medieval Slavic Archives of the Athonite Monastery of Kastamonitou, Cyrillomethodianum - Studies of the History of Greek-Slavic Relations vol. XX (2015): 153-216.

Петровић, В. 2015. Градски метох, у: Споменииа академика Милоша Благојевића (1930-2012), ур. С. Мишић, Београд: Филозофски факултет, Центар за историјску географију и историјску демографију, 139-150.

Петровић, В. и Булић, Д. 2009. Проблем убикације средњовековног Рудника, Историјски часопис LVIII, Београд, 43-62.

Поповић, М. 2002. Липовац - трагови средњовековног властеоског боравишта. $\mathrm{Ca}$ опитења XXXIV, Београд, 157-177.

Радисављевић, Д. 2020. Средњовековна Врбница и велики челник Радич Поступовић. Београдски историјски гласник 11: 73-97. 
Радичевић, Д. и Булић, Д. 2014. Прилог проучавању властеоске сахране у Моравској Србији, у: Власт и моћ - властела Моравске Србије од 1365. до 1402. године, Тематски зборник радова са међународног научног скупа одржаног од 20. до 22. септембра 2013. године у Крушевиу, Великом Шиљеговиу и Варварину, ур. проф. др С. Мишић, Крушевац, 113-135.

Рашковић, Д. 2011. Прилози познавању средњовековне топографије крушевачког краја. Крушевачки зборник 15: 153-181.

Рашковић, Д. 2015. Крушевачки крај у светлу нумизматичких налаза од антике до средњег века. Рад представљен на научном скупу „Црква Лазарица и Моравска Србија” 20. јуна 2015. године, Крушевац, 1-29.

Рашковић, Д. и Берић, Н. 2002. Резултати рекогносцирања античких и средњовековних налазишта трстеничке општине и суседних области. Гласник Српског археолошког друштва 18: 137-156.

Рашковић, Д., Димовски, Н. и Црнобрња, С. 2010. Рановизантијско утврђење Градиште у Љубинцима - Жупа александровачка. Жупски зборник 5: 29-56.

Ристић, В. 1996. Моравска архитектура. Крушевац: Народни музеј.

Српска православна црквена општина Велика Врбница, Завод за заштиту споменика културе, број: 167, 21. 04. 1992. године, Краљево (Документација Завода за заштиту споменика културе Краљево).

Станић, Р. 1975. Делатност завода за заштиту споменика културе у Краљеву од 1965. до 1975. године - Црква у Лаћиследу код Александровца. Рашка баштина 1: 312.

Стародубцев, Т. 2014. Писани извори о црквама и манастирима подизаним или обнављаним у областима Лазаревића и Бранковића. II Повеље. Саопштењь XLVI: 107-123.

Стародубцев, Т. 2016. Српско зидно сликарство у земљама Лазаревића и Бранковића. Књиге I и II. Београд: Универзитет у Београду, Филозофски факултет, Институт за историју уметности.

Стојановић, Љ. 1890. Стари српски хрисовуљи, акти, биографије, летописи, типици, поменици, записи и др., прибрао их Љуб. Стојановић, Споменик III, Београд: Државна штампарија Краљевине Србије.

Тошић, В. 1976. Велики челник Радич. Зборник за историју 13: 7-22.

Цветковић, Б. 1999. Манастир Липовац - прилог проучавању. Лесковачки зборник XXXIX: 79-100.

Црнобрња-Красић, С. 2020. Археологија у Жупи 2008-2020, Жупски зборник 10: 189-210. Шкриванић, Г. 1973. Властелинство великог челника Радича Поступовића. Историјски часопис XX: 125-137.

\section{KAPTE}

Генералитабна карта 1 : 75 000, секција Ж. 7. Крушевац, Географско одељење Главног Генералштаба, Београд, 1894. 
Topografska karta 1 : 25 000, Kuršumlija 1-2 (Kupci), broj lista 581-1-2, Vojnogeografski institut, Beograd, drugo izdanje, 1971, sadržaj dopunjen 1969. godine.

Topografska karta 1 : 25 000, Kruševac 3-4 (V. Drenova - jug), broj lista 531-3-4, Vojnogeografski institut, Beograd, drugo izdanje, 1971, sadržaj dopunjen 1969. godine.

\section{ЕЛЕКТРОНСКИ ПОРТАЛИ}

Званични сајт Крушевачке епархије, http://www.eparhijakrusevacka.com 


\title{
Dejan S. Radisavljević
}

Faculty of Philosophy, University of Belgrade

\section{REMAINS OF A MEDIEVAL CHURCH AT THE SITE OF CRKVINA IN LAĆISLED, NEAR ALEKSANDROVAC ŽUPSKI}

\author{
Keywords: Laćisled, Vrbnica, Župa Aleksandrovačka, veliki čelnik Radič, baština, \\ triconch church, Monastery of the Presentation of the Virgin Mary, architecture
}

The report presents the results of archaeological excavations of the remains of a church at the site of Crkvina, in the village of Laćisled, ca $10 \mathrm{~km}$ north-east of Aleksandrovac, in the region of Župa. The research was conducted in 1972 by the Cultural Monument Protection Institute, Kraljevo, and headed by O. Vukadin. Two pits (dimensions: $2 \times 3 \mathrm{~m}$ ) were excavated in the interior of the church. The yellow soil in them was sterile, and no mobile archaeological material was discovered. It was established that the foundations of the church had been dug-in $0.60 \mathrm{~m}$ into the soil, and that the plinth came out at $0.30 \mathrm{~m}$ from the exterior church wall. Four pits, also $2 \times 3 \mathrm{~m}$, were open along the outside face of the church walls, and four graves with well-preserved remains of the deceased were discovered in them. There were no other finds in the graves that would help us date the church necropolis. In the same year, after rescue archaeological excavations, the remains of church walls were conserved.

The church, with the internal dimensions of $10.50 \times 8.30 \mathrm{~m}$, has a triconch base, and it was built of hewn stone and larger river pebbles, bonded with off-white lime mortar, in relatively regular rows. The interior of the church was divided into three unequal bays by pairs of pilasters of different dimensions, which most likely carried the arches on which the dome rested. In the northern and southern walls of the altar apse, semi-circular on the outside and inside, there were niches, used for the liturgy of preparation (proscomedia) and by the deacon.

During the second decade of the $15^{\text {th }}$ century, the village of Vrbnica was a part of the land estate (baština) of the veliki čelnik Radič, which we learn from a charter issued by the Despot Đurad Vuković (1427-1456) to this nobleman in 1429/30. The Ottoman defter of the Kruševac Sanjak from 1516 also recorded the village of Vrbnica, whose other name is Laćisled. The village has retained its second name, Laćisled, to this days.

Judging by the analogy with the church in Kamenica, not far from Kragujevac, which was also a part of the land estates of the veliki čelnik Radič, archaeo- 
logically dated into the first half of the $15^{\text {th }}$ century, the church in Laćisled had to have been built before 1427/28, when the Turks conquered Kruševac and its surroundings. In Ottoman defters from the $16^{\text {th }}$ century, in addition to Vrbnica, i.e. Laćisled, the Monastery of the Presentation of the Virgin Mary (Manastir Prečistog Vavedenja) was also listed.

The modest remains of the church at the site of Crkvina in Laćisled represent an important historical, archaeological and architectural monument of the medieval heritage of Serbia, and Župa Aleksandrovačka in particular. 